\title{
Paternalism in the doctor-patient relationship, observations in the pandemic era
}

\author{
Cesar H. Gutiérrez-Aguirre* \\ Hematology Service, "Dr José E. González" University Hospital, Universidad Autónoma de Nuevo León, Monterrey, Nuevo Leon, Mexico
}

"I will use those dietary regimens which will benefit my patients according to my greatest ability and judgment, and I will do no harm or injustice to them."

Hippocrates (460 AC - 370 AC)

\section{Who should decide on the treatment for a patient?}

Bioethics is a relatively new science. However, the Hippocratic Oath already established that medical acts must be based on the bioethical principles of beneficence and non-maleficence, regardless of the autonomy principle. For a long time, traditional medical practice was centered on the physician, as he was the one who decided what was best for the patient. In contrast, the patient received the treatment or underwent a procedure without having much information about it. The classical image of a good patient was that of a patient who did not ask any questions and obeyed the physicians' indications verbatim. Authoritarian medical paternalism was the common practice. The Royal Spanish Academy defines paternalism as "the tendency to apply forms of authority and protections expected from a father in traditional families to social, political, or work relationships, etc.."

There are essentially two people involved in the doctor-patient relationship, of whom the most vulnerable is the patient. In addition to being sick, they lack the proper information about their illness, allowing them to make decisions. Today, easy access to internet search tools and engines allows patients to have more insight into their illness; however, the obtained information is often incorrect or misinterpreted, making the physician's informative labor essential.

Stepping back from authoritarian paternalism does not mean leaving the patient to their luck but respecting their autonomy and human dignity. For patients to exercise their autonomy, they would have to be previously informed by the physician about the different treatment options for their disease, including the process to be followed, costs, risks, benefits, and expected results. In this sense, one should consider that the patient can reject the options proposed by the physician. Nevertheless, the patient's treatments will always be adjusted to approved medical standards and availability. The patient's self-determination is presented in research as well as in clinical practice as informed consent.

Autonomy is part of human dignity; Aristoteles (384 BC- 322 BC) associated human dignity with the ability to have self-awareness and free will; respecting the patient's autonomy is respecting their dignity as a person. Decision-making ought to be shared between the doctor and his patient; the informative action of the physician must not be excluded even in those cases where the patient prefers not to make the decisions, adopting a passive role. There will be situations where the patient will not have the ability to make autonomous and responsible decisions. In these cases, special

\section{Correspondence:}

${ }^{*}$ Cesar H. Gutiérrez-Aguirre

E-mail: hematohu@yahoo.com license (http://creativecommons.org/licenses/by-nc-nd/4.0/)
Date of reception: 12-07-2021

Date of acceptance: 27-07-2021

DOI: 10.24875/RMU.M21000060
Available online: $18-10-2021$

Medicina Universitaria. 2021;23(3):76-77 www.medicinauniversitaria.org 
actions should be studied and assessed individually for each situation.

\section{Impact of the pandemic}

One of these special situations is, without a doubt, the one we are currently living with, the SARS-CoV-2 virus pandemic. The impact in different fields has been highly relevant, taking the doctor-patient relationship to unexpected and very particular circumstances. During these months of the pandemic, health-care personnel have had to make decisions faced with emergencies, like when the patient is not in an optimal condition to make decisions. There is not enough time to reach out to the person legally responsible for the patient to ask them for their consent, that is, to place an endotracheal tube for assisted ventilation, the onset of vasopressors, or admittance to the intensive care unit. In response to this conflict of bioethical principles, the doctor must act considering the ethic of the minimum, where the non-maleficence principles (to not harm) and justice (to give everyone what they deserve according to their needs) are hierarchically superior to autonomy and beneficence principles. In these emergency circumstances, if we do not have an anticipated power of attorney, medical personnel must perform the necessary procedures that the patient requires to preserve their life even though they lack the patient's informed consent. Despite the pandemic, we must never forget our universal ethical principles and the search for a better doctor-patient relationship.

\section{Conflicts of interest}

The author declares no conflicts of interest.

\section{Funding}

No funding was provided for this study.

\section{Ethical disclosures}

Protection of human and animal subjects. The authors declare that no experiments were performed on humans or animals for this study.

Confidentiality of data. The authors declare that no patient data appear in this article.

Right to privacy and informed consent. The authors declare that no patient data appear in this article.

\section{References}

1. Diccionario de la Lengua Española. Real Academia Española. Available from: https://www.rae.es. [Last accessed on 2021 Jul 07].

2. Villafranca RC, Guilhem D, Pérez KB. Paternalismo médico. Rev Méd Electrón. 2013;35:144-52.

3. Ogando B, García C. Veinticinco siglos de paternalismo, 25 años de autonomía: una aproximación histórica a los cambios en la relación clínica. Rev Calidad Asistencial. 2006;21:164-9. 